\title{
Exposure to 2,3,7,8-tetrachlorodibenzo-p-dioxin increases the activation of aryl hydrocarbon receptor and is associated with the aggressiveness of osteosarcoma MG-63 osteoblast-like cells
}

\author{
SHIH-CHIEH YANG ${ }^{1 *}$, CHIN-HSIEN WU $^{1 *}$, YUAN-KUN TU $^{1}$, SHIN-YU HUANG ${ }^{3}$ and PAI-CHIEN CHOU ${ }^{2,3}$ \\ ${ }^{1}$ Department of Orthopedic Surgery, E-Da Hospital, I-Shou University, Kaohsiung 82445; \\ ${ }^{2}$ Department of Thoracic Medicine, Saint Paul's Hospital, Taoyuan 33069; ${ }^{3}$ Department of Thoracic Medicine, \\ Chang Gung Medical Foundation, Chang Gung University, College of Medicine, Taoyuan 33305, Taiwan, R.O.C.
}

Received December 11, 2017; Accepted June 29, 2018

DOI: $10.3892 / \mathrm{ol} .2018 .9098$

\begin{abstract}
The aryl hydrocarbon receptor (AhR) is a liganddependent transcription factor whose activity is modulated by xenobiotics and physiological ligands. Activation of the AhR by environmental xenobiotics may induce a conformational change in AhR and has been implicated in a variety of cellular processes, including inflammation and tumorigenesis. It is unknown whether the activation of AhR serves a role in modulating the progression of osteosarcoma. The osteosarcoma cell line MG-63, was treated with AhR ligand, 2,3,7,8-tetrachlorodibenzo-p-dioxin (TCDD). TCDD treatment degrades AhR expression through activation of the AhR signaling pathway, however there were no survival differences observed in MG-63 cells. There were concomitant elevations of cyclooxygenase-2 and receptor activator of nuclear factor- $\kappa \mathrm{B}$ ligand secretion from MG-63 cells upon TCDD treatment on a protein and mRNA level at 24 and $72 \mathrm{~h}$. In addition, TCDD treatment also increases the production of prostaglandin E2 on MG-63 cells, and induces the expression of chemokine receptor CXCR4. However, CXCL12 production was not altered in MG-63 cells when stimulated with TCDD. The AhR antagonist CH-223191, blocks the effects on TCDD-induced RANKL, COX-2, PGE2 and CXCR4 changes. In conclusion, these findings suggest that AhR signal therapy should be further explored as a therapeutic option for the treatment of osteosarcoma.
\end{abstract}

Correspondence to: Dr Pai-Chien Chou, Department of Thoracic Medicine, Chang Gung Medical Foundation, Chang Gung University, College of Medicine, 5 Fushin Street, Kweishan Shiang, Taoyuan 33305, Taiwan, R.O.C.

E-mail: baechainchou@gmail.com

*Contributed equally

Key words: osteoblast, osteosarcoma, 2,3,7,8-tetrachlorodibenzop-dioxin, aryl hydrocarbon receptor, receptor activator of nuclear factor $\kappa \mathrm{B}$ ligand

\section{Introduction}

Bone homeostasis is maintained by a balance between bone resorption by osteoclasts and bone formation by osteoblasts (1). Osteoblasts not only play a central role in bone formation by synthesizing multiple bone matrix proteins, but also regulate osteoclast maturation by soluble factors like receptor activator of nuclear factor- $\mathrm{kB}$ ligand (RANKL) (2) and cognate interaction, resulting in bone resorption (3). The chemokine CXCL12 and its receptor CXCR4 play a key role in regulating hematopoietic stem cells and cell migratory function during morphogenesis (4). Osteoblasts express both the CXCL12 ligand and the CXCR4 receptor, provide regulatory feedback, and play a multifunctional role in regulating bone formation and resorption (5).

Recent evidence has shown that the ambient air pollution may be associated with increased bone turnover rate in children (6). High levels of osteocalcin, an osteoblast-specific gene expressed by fully differentiated osteoblasts (7), have been associated with long-term exposure to ambient air pollution (6). Among the pollutants, 2,3,7,8-tetrachlorodi-benzo-p-dioxin (TCDD) are by-products in the manufacturing of chlorophenols and chlorophenoxy herbicides and in other common processes such as combustions of fossil fuel. Evidence indicates that TCDD may promote liver and skin tumor formation through the inhibition of tumor senescence (8).

The aryl hydrocarbon receptor (AhR) is a ligand-dependent transcription factor whose activity is modulated by xenobiotics and physiological ligands (9). Ligand binding induces a conformational change in AhR, thereby exposing a nuclear translocation site leading to pathologic effects in both animals and humans (10). As a ligand to AHR, TCDD elicits toxicities through AhR (11) and on TCDD exposure, the activated AhR translocates to the nucleus, is dimerized by the $\mathrm{Ah}$ receptor nuclear translocator, and binds to dioxin response elements (DRE) in the genome (12). Studies on conditional AHR deficient mice demonstrate that AhR signal transduction is involved in the development of normal bone phenotype and in the manifestation of TCDD-induced bone alterations (13). Evidence indicates that dioxins may interfere with differentiation of osteoblasts and osteoclasts in TCDD 
concentrations as low as $100 \mathrm{fM}$ (14). Currently, dioxin and dioxin-like chemicals are not thought to be directly genotoxic. Their carcinogenic effect is likely the result of their tumor promoting activity produced by activation of the AhR (15).

Osteosarcoma is the most common primary malignant bone tumor affecting children and young adolescents (16). Composed of malignant osteoblasts producing immature bone or osteoid tissue, osteosarcomas can be subdivided histologically according to different cell forms (17). Several risk factors have been described, including high bone turnover issue, previous bone diseases, or heritable syndromes that predispose to osteosarcoma $(17,18)$. Environmental factors, such as radiation (19), is reported to increase the risk of osteosarcoma, but other environmental alterations are not well characterized.

Therefore, in the present study, we investigated the effects of TCDD treatment on the human osteosarcoma cell line, MG-63 cells and explored the AhR, RANKL and CXCR4/CXCL12 axis expressions on MG-63 cells in response to TCDD. We propose that TCDD, a ubiquitous environmental contaminant, may be associated with the aggressiveness of osteosarcoma. The results suggest that TCDD stimulation may mediate RANKL, COX-2, PGE2 and CXCR4 axis expressions and modulate the aggressiveness of osteosarcoma. The results further reveal novel signaling paradigms and regulatory networks that expand the understanding of the complex mechanisms involved in maintaining the homeostasis of MG-63 under TCDD stimulations.

\section{Materials and methods}

MG-63 osteosarcoma cell line culture. The osteosarcoma cell line, MG-63 cell (20), was purchased from the American Type Culture Collection (ATCC) Manassas, VA, USA, and cultivated in Dulbecco's modified Eagle's medium (DMEM) containing $10 \%$ FBS, according to the supplier's recommendations. The cells were cultured in a humidified incubator at $37^{\circ} \mathrm{C}$, using a standard mixture of $95 \%$ air and $5 \% \mathrm{CO}_{2}$. For passage, the cells were detached with trypsin/EDTA and subsequently re-plated and maintained in culture for 2-4 days before use. At $70 \%$ confluence, the cells were treated with 0.1, 1 or $10 \mathrm{nM}$ TCDD (Sigma-Aldrich, St. Louis, MO, USA) diluted in toluene, or with an equivalent volume of toluene alone $(0.2 \% \mathrm{vol} / \mathrm{vol})$.

Cell growth and viability assays. Cells $\left(100 \mu 1,2 \times 10^{4}\right.$ cells $\left./ \mathrm{ml}\right)$ were plated in 96-well plates and allowed to attach for $24 \mathrm{~h}$. The cells were then treated with $0,0.1,1$, or $10 \mathrm{nM}$ of TCDD for 24 and $72 \mathrm{~h}$. The proportion of viable cells was determined by MTT assay following the manufacturer's instructions. Briefly, the cells were incubated with MTT $(0.5 \mathrm{~g} / \mathrm{l})$ for $4 \mathrm{~h}$. The formazan precipitate was dissolved in $200 \mu$ l dimethyl sulfoxide (DMSO) and the absorbance at $550 \mathrm{~nm}$ was measured with a Benchmark microplate reader. The tumor inhibitory rate was calculated as (1 - OD experimental group/OD control group) $\mathrm{x} 100 \%$. The experiments were performed in triplicate.

Analysis of apoptosis and cell cycle arrest. Apoptosis induced by TCDD was quantified using the Annexin V-FITC Apoptosis Detection kit I (BD Biosciences, Franklin Lakes, NJ, USA). The MG-63 cells were treated with $0,0.1,1$ or $10 \mathrm{nM}$ of TCDD for 24 and $72 \mathrm{~h}$, and then washed twice with cold hosphatebuffered saline (PBS) and re-suspended in $1 \mathrm{X}$ binding buffer at a concentration of $1 \times 10^{6}$ cells $/ \mathrm{ml}$. The solution $(100 \mu 1$, $1 \times 10^{5}$ cells) was transferred to a $5-\mathrm{ml}$ culture tube and $5 \mu \mathrm{l}$ Annexin V-FITC and $5 \mu \mathrm{l}$ propidium iodide (PI) were added. The cells were gently vortexed and incubated for $15 \mathrm{~min}$ at room temperature $\left(25^{\circ} \mathrm{C}\right)$ in the dark. The $1 \mathrm{X}$ binding buffer (400 $\mu \mathrm{l})$ was added to each tube. Samples were analyzed by flow cytometry within $1 \mathrm{~h}$. Total cell apoptosis was defined as the sum of cells in early and late apoptosis. The experiments were performed in triplicate.

Antibodies and flow cytometry study for CXCR4 expressions. Briefly, $2 \times 10^{5}$ cells were incubated for $10 \mathrm{~min}$ at $4^{\circ} \mathrm{C}$ and stained with specific CXCR4 mouse anti-human monoclonal primary antibodies conjugated with FITC (cat. no. sc-12764 FITC; Santa Cruz Biotechnology, Inc., Dallas, TX, USA) based on the manufacturer's recommendations. To measure the CXCR4 expression on MG-63 cells, data were acquired on a FACSCalibur flow cytometer (BD Biosciences) using CellQuest software (BD Biosciences). At least 10,000 cells were analyzed per sample.

Enzyme-linked immune-sorbent assay (ELISA). Cells $2 \times 10^{5}$ were treated with $0,0.1,1$, or $10 \mathrm{nM}$ of TCDD for 24 and $72 \mathrm{~h}$, and then cultured in 24-well plates in medium $(500 \mu \mathrm{l})$ for 24 h. The Prostaglandin E2 ELISA Kit (cat. no. KA4522; Abnova, Taipei, Taiwan) was used to measure PGE2 metabolites in supernatants according to the manufacturer's protocol. The CXCL12 levels were quantified by commercially available ELISA kits (cat. no. DSA00; R\&D Systems, Inc., Minneapolis, MN, USA), according to the manufacturer's specifications. All samples were run in batches to minimize inter-assay variability, assayed in duplicate, and quantitated using a standard curve method.

Western blot analysis. The MG-63 cells $\left(5 \times 10^{5}\right)$ were plated and treated with $0,0.1,1$, or $10 \mathrm{nM}$ of TCDD for $24 \mathrm{~h}$, and then lysed with a buffer composed of $50 \mathrm{mmol} / \mathrm{l}$ Tris- $\mathrm{HCl}(\mathrm{pH} 8.0)$, $150 \mathrm{mmol} / 1 \mathrm{NaCl}, 0.1 \%$ Triton X-100, $0.01 \mathrm{~g} / 1$ aprotinin, and $0.05 \mathrm{~g} / 1$ phenylmethylsulfonyl fluoride. Protein was quantified by the Bradford method and equal amounts $(30 \mu \mathrm{g})$ of protein were loaded and electrophoresed on a $10 \%$ sodium dodecyl sulfate-polyacrylamide gel electrophoresis minigel. Proteins were transferred to a polyvinylidene fluoride (PVDF) membrane and pre-blocked with casein PBS and $0.05 \%$ Tween-20 for $1 \mathrm{~h}$ at room temperature. The membranes were incubated with mouse monoclonal antibody against AHR (1:500; cat. no. SC-133088; Santa Cruz Biotechnology, Inc.), rabbit polyclonal antibody against COX-2 (1:1,000; cat. no. ab52237), mouse monoclonal antibody against RANKL (1:250; cat. no. ab45039) (both from Abcam, Cambridge, UK), and mouse monoclonal antibody against $\beta$-actin (1:10,000; cat. no. MAB1501; EMD Millipore, Billerica, MA, USA) incubate at 4 Celsius degree overnight. Horseradish peroxidase-conjugated goat against mouse IgG antibody (1:1,000; cat. no. AP-124P; EMD Millipore) or goat against rabbit IgG antibody (1:750; cat. no. AP-132P; EMD Millipore) were used with incubation time of $1 \mathrm{~h}$ at room temperature. Protein bands were visualized with enhanced chemiluminescence reagent 
A $\operatorname{TCDD}(\mathrm{nM})$

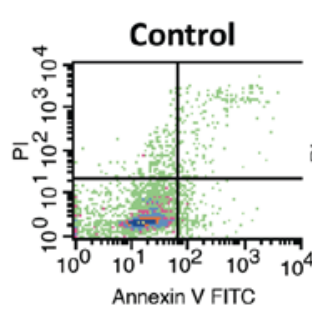

B

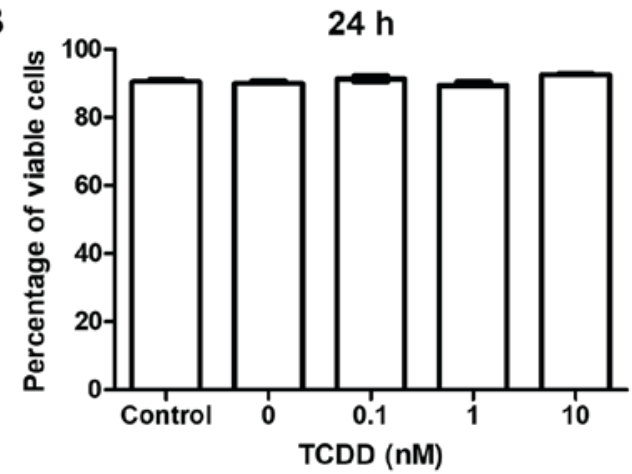

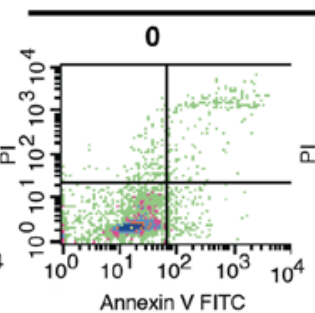

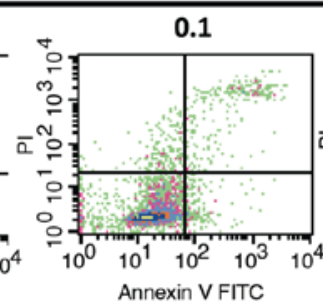

C

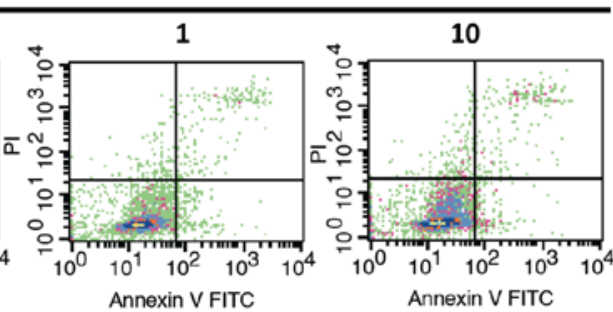

$72 \mathrm{~h}$

Figure 1. TCDD treatment did not increase proliferation or decrease the survival of MG-63 cells. Cells were treated with toluene (vehicle control) and 0.1 , 1 and $10 \mathrm{nM}$ TCDD. (A) Viable cells were evaluated by Annexin V/PI analysis through flow cytometry at (B) 24 and (C) 72 h. There were no survival differences between different treatments. The results were representative of three different experiments. TCDD, 2,3,7,8-tetrachlorodibenzo-p-dioxin; PI, propidium iodide.

(ECL Kit, Amersham, UK), and were then exposed to Kodar XAR film.

$R T-Q P C R$ and QPCR. Total RNA was isolated from cells using RNeasy kits (Qiagen, Inc., Valencia, CA, USA) according to the manufacturer's instructions. cDNA was reverse-transcribed from isolated RNA by incubating $200 \mathrm{ng}$ DNase-treated RNA with the first strand synthesis kit from Advanced Biotechnologies Ltd. (Surrey, UK) following the manufacturer's instructions. The QPCR was performed in a Rotor-Gene 6000 System (Corbett Life Science; Qiagen, Inc.). The PCR mixtures contained $0.5 \mu \mathrm{M}$ each of specific forward and reverse primers: 5'-GGCCACATCCGGGACATCACA GA-3 (sense) and 5'-GGGGGATGGTGAAGGGGACGAA-3' (antisense); for cytochrome P450 1A1 (Cypla1); 5'-GTCAAC GGATTTGGCGTATT-3' (sense) and 5'-AAAGTTGTCATG GATGACCTTGGC-3' (antisense) for GAPDH.

The samples were denatured at $95^{\circ} \mathrm{C}$ for $10 \mathrm{~min}$, followed by 30 cycles for Cypla1 $\left(95^{\circ} \mathrm{C}\right.$ for $15 \mathrm{sec}, 58^{\circ} \mathrm{C}$ for $5 \mathrm{sec}$, and $72^{\circ} \mathrm{C}$ for $\left.10 \mathrm{sec}\right), 30$ cycles for GAPDH $\left(95^{\circ} \mathrm{C}\right.$ for $15 \mathrm{sec}, 58^{\circ} \mathrm{C}$ for $5 \mathrm{sec}$, and $72^{\circ} \mathrm{C}$ for $\left.10 \mathrm{sec}\right)$. Melting curves were obtained at the end of amplification by cooling the samples to $65^{\circ} \mathrm{C}$ for $15 \mathrm{sec}$ followed by further cooling to $40^{\circ} \mathrm{C}$ for $30 \mathrm{sec}$. Data was analyzed by the standard curve method of absolute quantification method (21) using Corbett analysis software. In RT-QPCR, data was normalized with GAPDH.

Statistical analysis. The data presented were obtained from three separate experiments using cell cultures. Each experiment was performed in triplicate. One-way ANOVA (analysis of variance) for mixed design was used to compare hemodynamic values of more than two different experimental groups. If variance among groups was noted, a Bonferroni test was used to determine any significant difference between specific points within groups. The data were analyzed by Student's t-test for paired or unpaired data. For data with even or uneven variation, a Mann-Whitney $U$ test or Wilcoxon signed rank test was used for unpaired or paired data, respectively. The GraphPad Prism (version 5.0; GraphPad Software, San Diego, CA, USA) was used for all statistical analyses. Data are presented as the mean \pm standard error or the mean. Statistical significance was set at $\mathrm{P}<0.05$.

\section{Results}

TCDD treatment did not affect MG-63 survival. To test the hypothesis that TCDD treatment was not associated with survival, the MG-63 cells were treatment with toluene or $0.1,1$ or $10 \mathrm{nM}$ TCDD. The viable cells were counted at 24 and $72 \mathrm{~h}$ later by Annexin V and PI measurements via flow-cytometry. There were no statistically significant changes before $72 \mathrm{~h}$ of culture (Fig. 1).

MG-63 cells expressed a functional AhR under TCDD treatment. The amount of AhR protein was investigated in MG-63 cells treated with toluene or $0.1,1$ or $10 \mathrm{nM}$ TCDD for 24 and $72 \mathrm{~h}$. The protein was detected in MG-63 cells and the TCDD treatment decreased the amounts of AhR protein (Fig. 2A) in a dose-dependent manner. This, in turn, was reported to be controlled by the ubiquitin-proteasome pathway (22). However, TCDD treatment increased the expression of the AhR-regulated gene, Cypla1, after 6 and $24 \mathrm{~h}$ (Fig. 2B and C), indicating that AhR pathway was responsive to TCDD and participated in DRE-mediated signaling in MG-63 cells.

TCDD treatment increased cyclooxygenase-2 (COX-2) and RANKL production. Aside from AhR activation, activated 
A
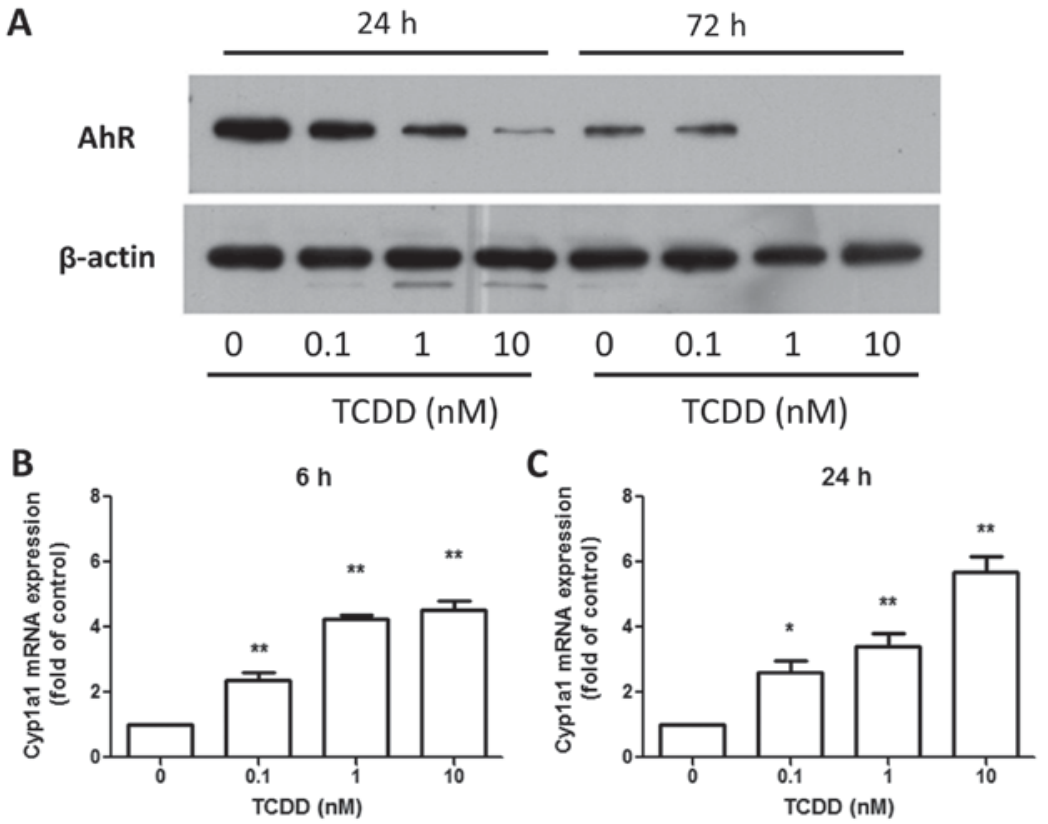

Figure 2. TCDD treatment degrades AhR expression in MG-63 cells and expresses functional AhR. MG-63 cells were treated with toluene (vehicle control) and $0.1,1$ and $10 \mathrm{nM}$ TCDD for 24 and $72 \mathrm{~h}$. (A) Western blot analysis revealed that AhR was degraded in a dose-dependent manner following TCDD treatment. The level of Cypla1 was quantitated by reverse transcription-polymerase chain reaction, which demonstrated an upregulation following TCDD treatment for (B) 6 and (C) $24 \mathrm{~h}$. Results were representative of three different experiments. Data are presented as the mean \pm standard error of the mean ( $\mathrm{n}=3$ ). "P<0.05, ${ }^{* *} \mathrm{P}<0.01$ vs. the toluene-treated cells. TCDD, 2,3,7,8-tetrachlorodibenzo-p-dioxin; AhR, aryl hydrocarbon receptor; Cyp1a1, cytochrome P450 1A1.



Figure 3. TCDD treatment increased COX-2 and RANKL expressions on protein levels. Cells were treated with toluene (vehicle control) and $0.1,1$ and $10 \mathrm{nM}$ TCDD for 24 and $72 \mathrm{~h}$. (A) COX-2 and RANKL protein levels were measured by western blot analysis. (B) COX-2 protein levels at 24 and $72 \mathrm{~h}$. Data are presented as the mean \pm standard error of the mean $(\mathrm{n}=3)$. (C) RANKL protein levels at 24 and $72 \mathrm{~h}$. ${ }^{*} \mathrm{P}<0.05$ and ${ }^{* *} \mathrm{P}<0.01$ vs. the toluene-treated control $(\mathrm{n}=3)$. TCDD, 2,3,7,8-tetrachlorodibenzo-p-dioxin; COX-2, cyclooxygenase-2; RANKL, receptor activator of nuclear factor- $\kappa \mathrm{B}$ ligand. 
A
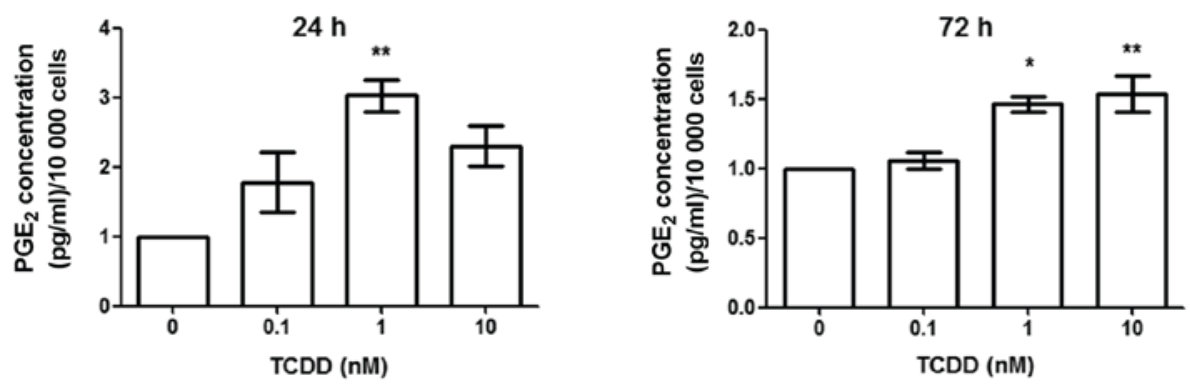

B

$\operatorname{TCDD}(\mathrm{nM})$
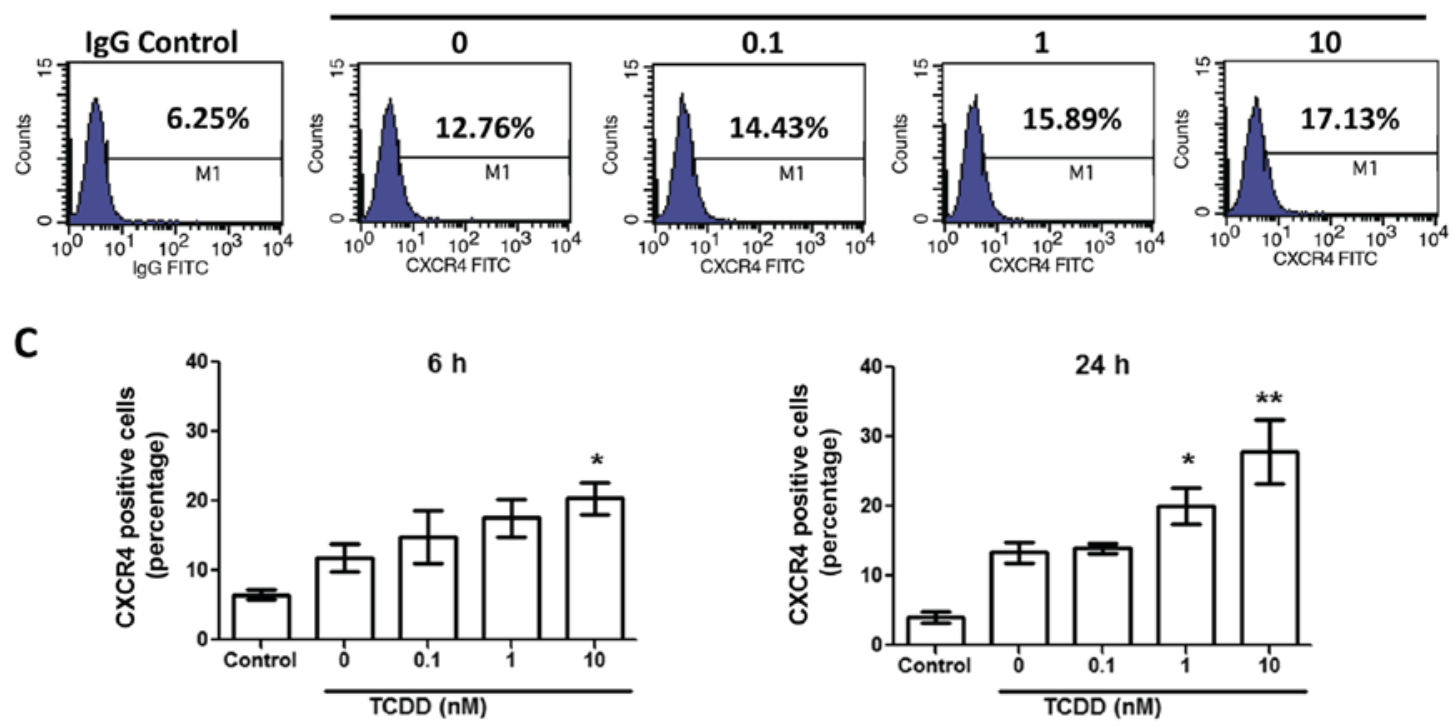

Figure 4. TCDD treatment increased PGE2 production and CXCR4 expression by MG-63 cells. (A) Cells were treated with toluene (vehicle control) and $0.1,1$ and $10 \mathrm{nM}$ TCDD for 24 and $72 \mathrm{~h}$. PGE2 protein levels in the supernatants were measured by ELISA. Data are presented as the mean \pm standard error of the mean $(\mathrm{n}=3)$. (B) CXCR4 receptor expressions were measured by flow cytometry after $6 \mathrm{~h}$ treatment. M1 denoted the cells presented with CXCR4 expressions . The number represented the percentage of total cells. (C) CXCR4 expressions following treatment were measured after 6 and $24 \mathrm{~h} .{ }^{*} \mathrm{P}<0.05$ and ${ }^{* *} \mathrm{P}<0.01$ vs. the toluene-treated control $(\mathrm{n}=3)$. TCDD, 2,3,7,8-tetrachlorodibenzo-p-dioxin; PGE2, prostaglandin E2.

MG-63 by TCDD upregulated RANKL expression around $24 \mathrm{~h}$ at the protein level (Fig. 3). This was linked to the regulation of bone resorption through the effects on osteoclasts. However, the effects were not seen after TCDD treatment for $72 \mathrm{~h}$ (Fig. 3C). The COX-2 expressions were elevated at the protein level (Fig. 3B) after TCDD treatment for 24 and $72 \mathrm{~h}$.

TCDD treatment increased prostaglandin E2 (PGE2). To test the impact of TCDD treatment on MG-63 cells activation mediated by the COX-2/PGE2 cascade, the PGE2 level was measured by ELISA after treated with toluene, $0.1,1$ and $10 \mathrm{nM}$ TCDD for 24 and $72 \mathrm{~h}$ (Fig. 4A). There was a marked increase in PGE2 levels after 24 and $72 \mathrm{~h}$ in the presence of TCDD. Together with the elevated COX-2 level, this finding suggests that TCDD treatment may promote the activation of the COX-2/PGE2 pathways.

TCDD treatment increased CXCR 4 expressions. To determine if TCDD treatment enhanced CXCR4 expression, MG-63 cells were cultured for 6 and $24 \mathrm{~h}$ with toluene, $0.1,1$ and $10 \mathrm{nM}$ TCDD. The CXCR4 expressions were then measured by flow cytometry (Fig. 4B). The results demonstrated that CXCR4 expressions were upregulated in a relatively dose-dependent manner at 6 and $24 \mathrm{~h}$ (Fig. 4C).

TCDD treatment did not increase CXCL12 production. CXCL12 production was measured by ELISA method, which revealed that CXCL12 production did not change between toluene- and TCDD-treated cells at $24 \mathrm{~h}$ (Fig. 5A) and $72 \mathrm{~h}$ (Fig. 5B). However, there were trends towards decreased production of CXCL12 when treated under $10 \mathrm{nM}$ TCDD at $24 \mathrm{~h}$ (ratio compared to vehicle control, $0.701 \pm 0.109, \mathrm{P}<0.05$ ).

Effects of AhR Antagonists on TCDD induced AhR, RANKL, COX-2, PGE2, CXCR4 and CXCL12 changes in MG-63 cells. To study whether the TCDD induced protein changes are AhR pathway related, AhR antagonist CH-223191 (10 $\mu \mathrm{m}$, Selleckchem, Houston, USA) blocks the TCDD-mediated suppression of AhR (Fig. 6B), RANKL (Fig. 6D), and COX-2 (Fig. 6C) expressions after treated by TCDD for 72 h. Meanwhile, CH-223191 also abrogated TCDD induced increasements of PGE2 (Fig. 7A) levels and CCR4 (Fig. 7B) expressions on MG-63 cells. However, there were no significant changes on TCDD induced CXCL12 (Fig. 7C) expressions when treated with $\mathrm{CH}-223191$. 

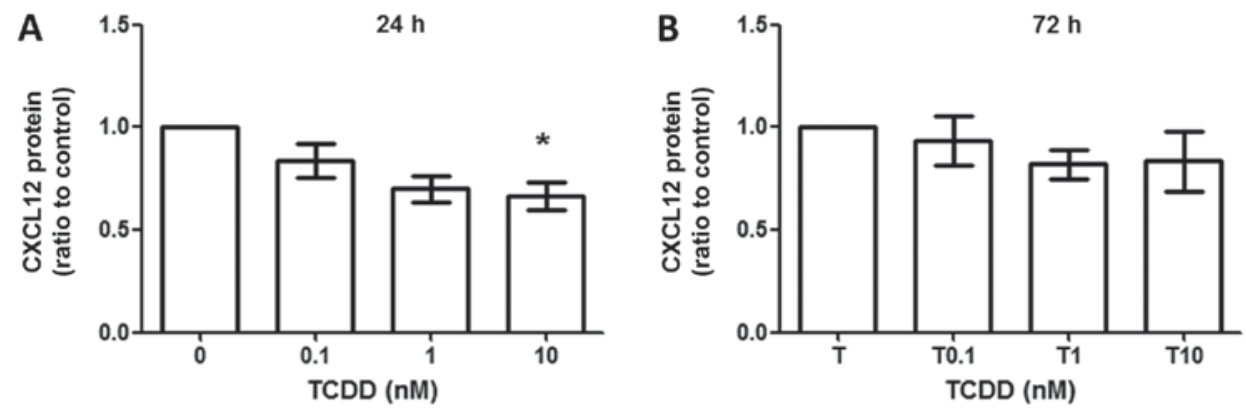

Figure 5. TCDD treatment did not increase CXCL12 production by MG-63 cells. MG-63 cells were cultured for $24 \mathrm{~h}$ with toluene (vehicle control), $0.1,1$ and $10 \mathrm{nM}$ TCDD treatment. (A) CXCL12 protein production in supernatants after $24 \mathrm{~h}$ was measured by ELISA. (B) CXCL12 protein production in supernatants after $72 \mathrm{~h}$. Data are presented as the mean \pm standard error of the mean $(\mathrm{n}=3)$. ${ }^{*} \mathrm{P}<0.05$ vs. the toluene-treated control $(\mathrm{n}=3)$. TCDD, 2,3,7,8-tetrachlorodibenzo-p-dioxin.
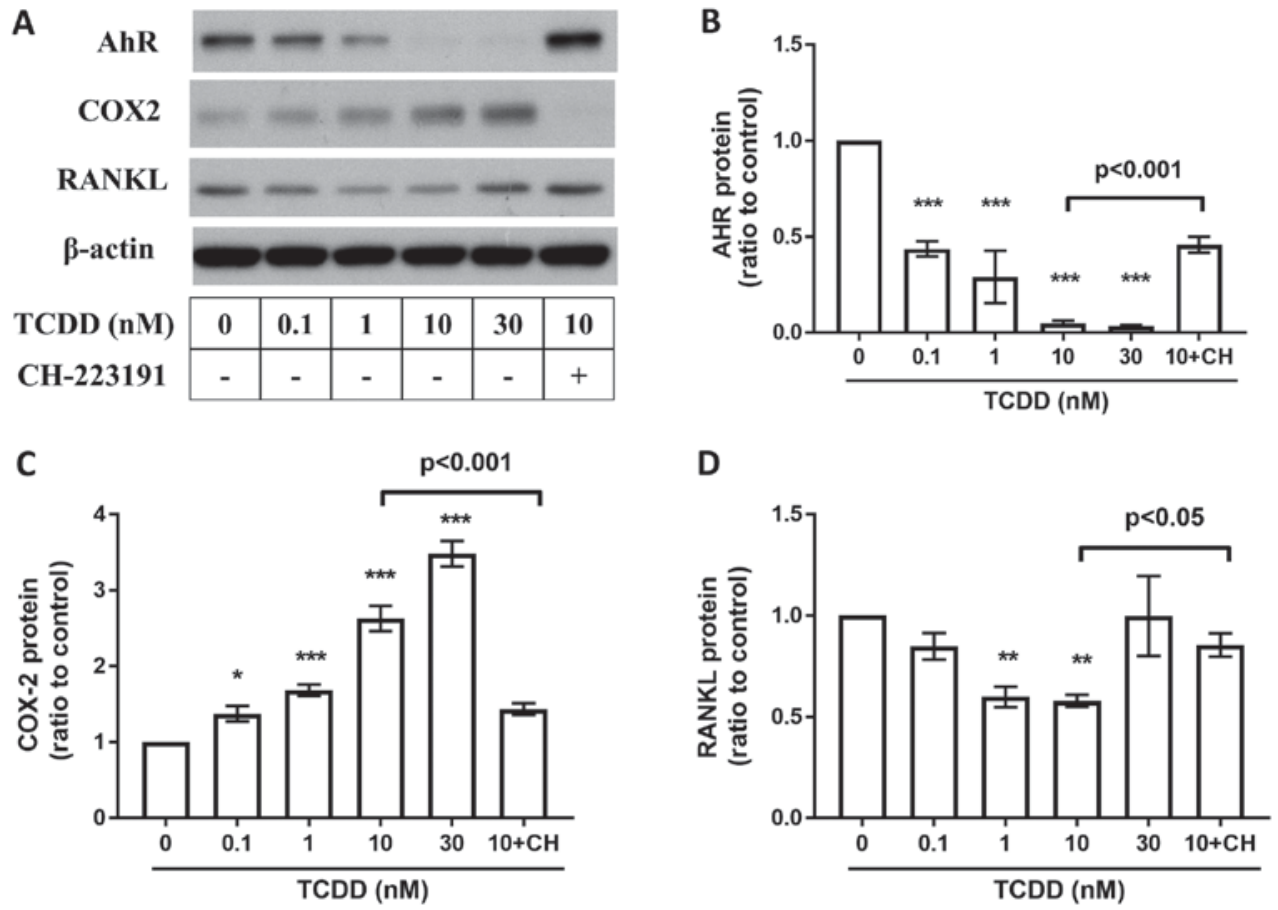

Figure 6. Effects of AhR Antagonists on AhR, COX-2, RANKL, and PGE2, CXCR4, CXCL12 expressions. MG-63 cells were cultured for $72 \mathrm{~h}$ with toluene (vehicle control), $10 \mathrm{nM}$ TCDD and $10 \mathrm{nM}$ TCDD plus CH-223191 for $72 \mathrm{~h}$. (A) AhR, COX-2 and RANKL protein levels were measured by western blot analysis. (B) AhR protein levels at $72 \mathrm{~h}$. (C) COX-2 protein levels at $72 \mathrm{~h}$. (D) RANKL protein levels at $72 \mathrm{~h}$. Data are presented as the mean \pm standard error of the mean ( $\mathrm{n}=3) .{ }^{*} \mathrm{P}<0.05,{ }^{* *} \mathrm{P}<0.01$ and ${ }^{* * *} \mathrm{P}<0.005$ vs. the toluene-treated control (n=3). CH, $10 \mu \mathrm{M} \mathrm{CH}-223191$; TCDD, 2,3,7,8-tetrachlorodibenzo-p-dioxin; COX-2, cyclooxygenase-2; RANKL, receptor activator of nuclear factor- $\kappa \mathrm{B}$ ligand.
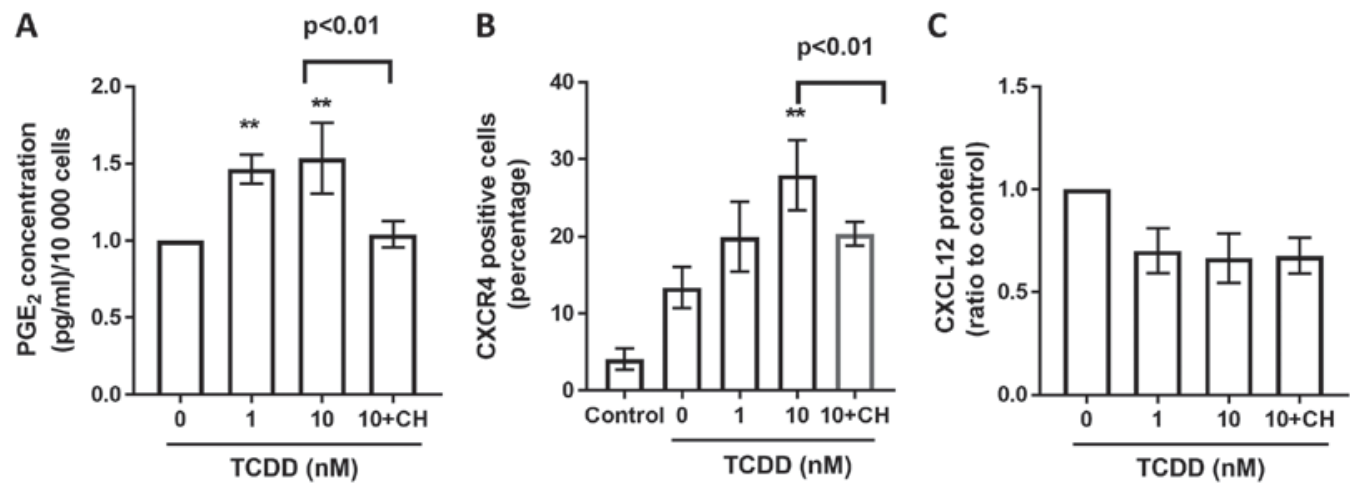

Figure 7. PGE2, CXCR4, CXCL12 profiles derived from MG-63 cells treated with AhR agonists. (A) Cells were treated with toluene (vehicle control), 1 or $10 \mathrm{nM}$ TCDD and $10 \mathrm{nM}$ TCDD plus CH-223191 for $72 \mathrm{~h}$. PGE2 protein levels in the supernatants were measured by ELISA. (B) CXCR4 receptor expressions were measured by flow cytometry after toluene (vehicle control), $1 \mathrm{nM}, 10 \mathrm{nM}$ TCDD and $10 \mathrm{nM}$ TCDD plus CH-223191 treatment for $24 \mathrm{~h}$. The number represented the percentage of total cells. (C) CXCL12 protein production in the supernatant after cells were treated with toluene (vehicle control), $1 \mathrm{nM}, 10 \mathrm{nM}$ TCDD and $10 \mathrm{nM}$ TCDD plus CH-223191 for $24 \mathrm{~h}$ was measured by ELISA. Data are presented as the mean \pm standard error of the mean ( $\mathrm{n}=3$ ). ${ }^{* * *} \mathrm{P}<0.01 \mathrm{vs.}$ the toluene-treated control (n=3). CH, $10 \mu \mathrm{M} \mathrm{CH}-223191$; TCDD, 2,3,7,8-tetrachlorodibenzo-p-dioxin; AhR, aryl hydrocarbon receptor; PGE2, prostaglandin E2. 


\section{Discussion}

The present study investigated how TCDD treatment affected the activation of the osteosarcoma cell line, MG-63 cell. Currently, there are only limited studies on the environmental impact on osteosarcoma and on osteoblast functions. Previous studies have pointed out differences in gene expression profiles of osteosarcoma cell lines and normal osteoblasts $(23,24)$. However, among the currently available osteosarcoma cells lines, Saos-2 cells have the most mature osteoblastic labeling profile, while U-2 OS cells are negative for most of the investigated osteoblastic markers (25). The MG-63 cells are the intermediate cell type in terms of differences in extracellular matrix formation. Recently, Miki et al (26) reported AhR influenced by environmental compounds, such as 3-methylcholanthrene (3-MC) and $\beta$-naphthoflavone ( $\beta-\mathrm{NF})$, could regulate estrogen synthesis and metabolism in bone tissues through cytokine/aromatase signaling based on a hFOB cell and MG-63 cell line model. These increments of AhR-target genes in MG-63 cells were inhibited by co-treatment of AhR antagonist, $\mathrm{CH}-223191$. Compare to the study, we try to investigate the effect of TCDD at a lower concentration which is more physiological feasible. Our results showed that the expressions of RANKL, COX-2, PGE2 and CXCR4 were upregulated under TCDD treatment, and inhibited by co-treatment of $\mathrm{CH}-223191$. Our findings further expand the knowledge on genes mediated by AhR pathway in MG-63 cell line even under low concentration of TCDD, and possibly linked to the aggressiveness in osteosarcoma.

The AhR, a ligand-activated transcriptional regulator, is ubiquitously expressed in most organs and can be activated by a structurally diverse range of chemicals $(27,28)$. The best-characterized ones include a variety of environmental contaminants. Gathered evidence point to the pro-inflammatory role of TCDD via activation of the AhR pathway, and modulation of bone microarchitecture and material properties (13). The TCDD are possible carcinogens but the risks are not closely linked to dose exposure $(29,30)$. Evidence indicates that dioxins may interfere with differentiation of osteoblasts and osteoclasts in TCDD concentrations as low as $100 \mathrm{fM}$ (14). Thus, we propose that TCDD, a ubiquitous environmental contaminant, may be associated with the aggressiveness of osteosarcoma even under low concentrations of exposure.

The TCDD concentrations used in the present study were between 0-10 nM were based on the previous epidemiology study investigated on the historical event that happened on 10 July 1976, a chemical explosion in Seveso, Italy, that resulted in the highest known residential exposure to TCDD (31). The median (interquartile range) serum TCDD concentration soon after the explosion was 73.2 (33.1-193.0) Parts Per Trillion (ppt) for all women, and roughly equals to $0.22(0.10-0.60) \mathrm{nM}$. In our results, TCDD treatment may the upregulation of RANKL under low concentrations $(0.1$ and $1 \mathrm{nM})$ at early time point, which indicates that TCDD may be associated with aggressiveness of MG-63 cells through the interaction with osteoclasts under different concentrations of TCDD exposure (32).

In our study, the amounts of Cyclooxygenase-2 (COX-2) protein are persistently elevated at 24 and $72 \mathrm{~h}$ after TCDD treatment. Currently, COX-2 expression has also been established as a marker in human osteosarcoma (33). COX-2 may mediates increased PGE2 production in bone in response to various stimuli including parathyroid hormone (PTH), mechanical strain, or inflammatory cytokines (34). TCDD can stimulate COX-2 expression through both a nongenomic pathway or activation of the AhR pathway (35). The alterations to COX-2 expression and the abundance of its enzymatic product PGE2 have key roles in influencing the development, progression, and metastasis potentials of cancer (36).

PGE2 was essential both for expression of functional CXCR4 and for production of its ligand CXCL12 in cancerassociated MDSCs model (37). The increased expression of CXCR4 may be a possible factor leading to the migration and proliferation abilities in a variety of tumors (38). Gathered evidence support that that TCDD is involved in the regulation of CXCR4/CXCL12 axis. In a comprehensive study, Hsu et al (39) reported that TCDD downregulates CXCR4 mRNA in five of 19 cell lines tested, but also upregulates CXCR4 mRNA in seven of the cell lines tested. Variations on the CXCL12 expressions on the cell lines are also seen (39). Using AhR antagonist, Yun et al (40) reported that TCDD induced CXCR4 in an AhR dependent manner. These findings indicate that CXCR4/CXCL12 are different mediated according to cells and microenvironments differences.

Results of our present analysis reveal that CXCR4 expression are increased after TCDD treatment in a dose response manner. Levels of CXCL12 showed the trends toward decreasing after TCDD treatment, but the differences are not statistically different. While the TCDD induced expression of COX-2, PGE2 and CXCR4 are blocked by the co-administration of AHR antagonist, $\mathrm{CH}-223191$, our findings revealed that AHR pathway are involved in the regulation of COX-2, PGE2 and CXCR4.

Current evidences revealed that RANKL are considered as a possibly hopeful therapeutic target molecule for osteosarcoma patients. In a recent study, IHC results demonstrate RANKL expression was observed in the tumor element in $68 \%$ of human osteosarcoma (41). However, the staining intensity was relatively low and only $37 \%$ of samples exhibited equal or mayor $10 \%$ RANKL positive tumor cells; moreover, RANK expression was not observed in OS tumor cells (41). The absence of RANK expression in primary human OS cells suggests that an autocrine RANKL/RANK signaling in human OS tumor cells is not operative. However, in a wholebody Rankl deletion mouse model, Chen et al (42) provide a rationale to consider RANKL blockade for the treatment and prevention of aggressive RANKL-overexpressing OS. This finding indicates that RANKL is associated with disease prognosis. Our results demonstrate that the RANKL is increased initially at $24 \mathrm{~h}$ under low concentrations of TCDD, but decreased at $72 \mathrm{~h}$, and are increased under the AhR antagonist $\mathrm{CH}-223191$. These findings indicate that the effect of TCDD on RANKL are complicated. More comprehensive studies are needed to establish possible treatment considerations for patients with osteosarcoma.

In conclusion, our results indicate that chronic TCDD exposure on MG-63 cells may be associated with clinical aggressiveness through the upregulation of COX-2, PGE2, and CXCR4. However, the TCDD induced RANKL expressions need to be investigated under different concentration and time points. Therefore, the results of our present study did indicate 
that TCDD could possibly disturb MG-63 cell homeostasis by disrupting the AhR pathway. Taken together, these findings suggest that 'AhR signal therapy' should be further explored as a therapeutic option in the treatment of osteosarcoma.

\section{Acknowledgements}

The authors would like to acknowledge Mr. Ho Chung Ju and Ms. Huang Tzu Ting (Department of Thoracic Medicine, Chang Gung University, Taoyuan, Taiwan) for their technical assistance with antibody preparations during the experiments.

\section{Funding}

The present study was supported by grants from the E-Da Hospital and I-Shou University (grant no. EDAHP103025) and the Chang Gung Memorial Hospital (grant no. CMRPG3E0731).

\section{Availability of data and materials}

All data generated or analyzed during this study are included in this published article.

\section{Authors' contributions}

SYH and PCC performed the experiments. PCC, SCY and $\mathrm{CHW}$ were responsible for the acquisition and analysis of the data. SCY, YKT and PCC conceived and designed the study. SYH and PCC contributed reagents, materials and analysis tools. SCY and PCC wrote the paper and gave final approval of the submitted manuscript. All authors have read and approved the final manuscript.

\section{Ethics approval and consent to participate}

Not applicable.

\section{Patient consent for publication}

Not applicable.

\section{Competing interests}

The authors declare that they have no competing interests.

\section{References}

1. Harada S and Rodan GA: Control of osteoblast function and regulation of bone mass. Nature 423: 349-355, 2003.

2. Trieb K and Windhager R: Receptor activator of nuclear factor $\kappa \mathrm{B}$ expression is a prognostic factor in human osteosarcoma. Oncol Lett 10: 1813-1815, 2015.

3. Caetano-Lopes J, Canhão H and Fonseca JE: Osteoblasts and bone formation. Acta Reumatol Port 32: 103-110, 2007.

4. Yellowley C: CXCL12/CXCR4 signaling and other recruitment and homing pathways in fracture repair. Bonekey Rep 2: 300, 2013.

5. Shahnazari M, Chu V, Wronski TJ, Nissenson RA and Halloran BP: CXCL12/CXCR4 signaling in the osteoblast regulates the mesenchymal stem cell and osteoclast lineage populations. FASEB J 27: 3505-3513, 2013.
6. Liu C, Fuertes E, Flexeder C, Hofbauer LC, Berdel D, Hoffmann B, Kratzsch J, von Berg A and Heinrich J; GINIplus Study Group; LISAplus Study Group: Associations between ambient air pollution and bone turnover markers in 10-year old children: Results from the GINIplus and LISAplus studies. Int J Hyg Environ Health 218: 58-65, 2015.

7. Qi H, Aguiar DJ, Williams SM, La Pean A, Pan W and Verfaillie CM: Identification of genes responsible for osteoblast differentiation from human mesodermal progenitor cells. Proc Natl Acad Sci USA 100: 3305-3310, 2003.

8. Ray S and Swanson HI: Activation of the aryl hydrocarbon receptor by TCDD inhibits senescence: A tumor promoting event? Biochem Pharmacol 77: 681-688, 2009.

9. Barouki R, Coumoul X and Fernandez-Salguero PM: The aryl hydrocarbon receptor, more than a xenobiotic-interacting protein. FEBS Lett 581: 3608-3615, 2007.

10. Veldhoen M, Hirota K, Westendorf AM, Buer J, Dumoutier L, Renauld JC and Stockinger B: The aryl hydrocarbon receptor links TH17-cell-mediated autoimmunity to environmental toxins. Nature 453: 106-109, 2008.

11. Mimura $\mathbf{J}$ and Fujii-Kuriyama Y: Functional role of $A h R$ in the expression of toxic effects by TCDD. Biochim Biophys Acta 1619: 263-268, 2003.

12. Harvey WA, Jurgensen K, Pu X, Lamb CL, Cornell KA, Clark RJ, Klocke C and Mitchell KA: Exposure to 2,3,7,8-tetrachlorodibenzo-p-dioxin (TCDD) increases human hepatic stellate cell activation. Toxicology 344-346: 26-33, 2016.

13. Herlin M,Finnilä MA,Zioupos P, Aula A, Risteli J, Miettinen HM, Jämsä T, Tuukkanen J, Korkalainen M, Håkansson $\mathrm{H}$, et al: New insights to the role of aryl hydrocarbon receptor in bone phenotype and in dioxin-induced modulation of bone microarchitecture and material properties. Toxicol Appl Pharmacol 273: 219-226, 2013.

14. Korkalainen M, Kallio E, Olkku A, Nelo K, Ilvesaro J, Tuukkanen J, Mahonen A and Viluksela M: Dioxins interfere with differentiation of osteoblasts and osteoclasts. Bone 44: 1134-1142, 2009

15. Schwarz $M$ and Appel KE: Carcinogenic risks of dioxin: Mechanistic considerations. Regul Toxicol Pharmacol 43: 19-34, 2005.

16. Garcia-Moure M, Martinez-Vélez N, Patiño-García A and Alonso MM: Oncolytic adenoviruses as a therapeutic approach for osteosarcoma: A new hope. J Bone Oncol 9: 41-47, 2016.

17. Kansara M, Teng MW, Smyth MJ and Thomas DM: Translational biology of osteosarcoma. Nat Rev Cancer 14: 722-735, 2014.

18. Dalla-Torre CA, de Toledo SRC, Yoshimoto M, Petrilli AS, Andrade JA, Chilton-MacNeill S, Squire JA and Zielenska M: Expression of major vault protein gene in osteosarcoma patients. J Orthop Res 25: 958-963, 2007.

19. Le Vu B, de Vathaire F, Shamsaldin A, Hawkins MM, Grimaud E, Hardiman C, Diallo I, Vassal G, Bessa E, Campbell S, et al: Radiation dose, chemotherapy and risk of osteosarcoma after solid tumours during childhood. Int J Cancer 77: 370-377, 1998.

20. Chang YY, Huang HL, Chen YC, Hsu JT, Shieh TM and Tsai MT: Biological characteristics of the MG-63 human osteosarcoma cells on composite tantalum carbide/amorphous carbon films. PLoS One 9: e95590, 2014.

21. Svec D, Tichopad A, Novosadova V, Pfaffl MW and Kubista M: How good is a PCR efficiency estimate: Recommendations for precise and robust qPCR efficiency assessments. Biomol Detect Quantif 3: 9-16, 2015.

22. Ma Q and Baldwin KT: 2,3,7,8-Tetrachlorodibenzo-p-dioxin -induced degradation of aryl hydrocarbon receptor (AhR) by the ubiquitin-proteasome pathway. Role of the transcription activaton and DNA binding of AhR. J Biol Chem 275: 8432-8438, 2000.

23. Benayahu D, Shur I, Marom R, Meller I and Issakov J: Cellular and molecular properties associated with osteosarcoma cells. J Cell Biochem 84: 108-114, 2001.

24. Bilbe G, Roberts E, Birch M and Evans DB: PCR phenotyping of cytokines, growth factors and their receptors and bone matrix proteins in human osteoblast-like cell lines. Bone 19: 437-445, 1996.

25. Pautke C, Schieker M, Tischer T, Kolk A, Neth P, Mutschler W and Milz S: Characterization of osteosarcoma cell lines MG-63, Saos-2 and U-2 OS in comparison to human osteoblasts. Anticancer Res 24: 3743-3748, 2004.

26. Miki Y, Hata S, Ono K, Suzuki T, Ito K, Kumamoto H and Sasano H: Roles of Aryl hydrocarbon receptor in aromatasedependent cell proliferation in human osteoblasts. Int J Mol Sci 18: pii: E2159, 2017 
27. Denison MS and Nagy SR: Activation of the aryl hydrocarbon receptor by structurally diverse exogenous and endogenous chemicals. Annu Rev Pharmacol Toxicol 43: 309-334, 2003.

28. Denison MS, Soshilov AA, He G, DeGroot DE and Zhao B: Exactly the same but different: Promiscuity and diversity in the molecular mechanisms of action of the Aryl hydrocarbon (Dioxin) receptor. Toxicol Sci 124: 1-22, 2011.

29. Walker NJ: Unraveling the complexities of the mechanism of action of dioxins. Toxicol Sci 95: 297-299, 2007.

30. Huff J, Lucier G and Tritscher A: Carcinogenicity of TCDD Experimental, mechanistic, and epidemiologic evidence. Annu Rev Pharmacol Toxicol 34: 343-372, 1994.

31. Eskenazi B, Warner M, Sirtori M,Fuerst T, Rauch SA, Brambilla P, Mocarelli P and Rubinacci A: Serum dioxin concentrations and bone density and structure in the Seveso Women's Health Study. Environ Health Perspect 122: 51-57, 2014.

32. Clohisy JC, Frazier E, Hirayama T and Abu-Amer Y: RANKL is an essential cytokine mediator of polymethylmethacrylate particle-induced osteoclastogenesis. J Orthop Res 21: 202-212, 2003.

33. Qu L and Liu B: Cyclooxygeanse-2 promotes metastasis in osteosarcoma. Cancer Cell Int 15: 69, 2015.

34. Rezzonico R, Schmid-Alliana A, Romey G, Bourget-Ponzio I, Breuil V, Breittmayer V, Tartare-Deckert S, Rossi B and Schmid-Antomarchi H: Prostaglandin E2 induces interaction between hSlo potassium channel and Syk tyrosine kinase in osteosarcoma cells. J Bone Miner Res 17: 869-878, 2002.

35. Yu Y, Liu Q, Guo S, Zhang Q, Tang J, Liu G, Kong D, Li J, Yan S, Wang R, et al: 2,3,7,8-Tetrachlorodibenzo- $p$-dioxin promotes endothelial cell apoptosis through activation of EP3/p38MAPK/Bcl-2 pathway. J Cell Mol Med 21: 3540-3551, 2017.

36. Greenhough A, Smartt HJ, Moore AE, Roberts HR, Williams AC, Paraskeva $\mathrm{C}$ and Kaidi A: The COX-2/PGE2 pathway: Key roles in the hallmarks of cancer and adaptation to the tumour microenvironment. Carcinogenesis 30: 377-386, 2009.
37. Obermajer N, Muthuswamy R, Odunsi K, Edwards RP and Kalinski P: PGE2-induced CXCL12 production and CXCR4 expression controls the accumulation of human MDSCs in ovarian cancer environment. Cancer Res 71: 7463-7470, 2011.

38. Lu Y, Guan GF, Chen J, Hu B, Sun C, Ma Q, Wen YH, Qiu XC and Zhou Y: Aberrant CXCR4 and $\beta$-catenin expression in osteosarcoma correlates with patient survival. Oncol Lett 10: 2123-2129, 2015.

39. Hsu EL, Yoon D, Choi HH, Wang F, Taylor RT, Chen N, Zhang R and Hankinson $\mathrm{O}$ : A proposed mechanism for the protective effect of dioxin against breast cancer. Toxicol Sci 98: 436-444, 2007.

40. Yun C, Katchko KM, Schallmo MS, Jeong S, Yun J, Chen CH, Weiner JA, Park C, George A, Stupp SI, et al: Aryl hydrocarbon receptor antagonists mitigate the effects of dioxin on critical cellular functions in differentiating human osteoblast-like cells. Int J Mol Sci 19: pii: E225, 2018.

41. Branstetter D, Rohrbach K, Huang LY, Soriano R, Tometsko M, Blake M, Jacob AP and Dougall WC: RANK and RANK ligand expression in primary human osteosarcoma. J Bone Oncol 4: 59-68, 2015.

42. Chen Y,Di Grappa MA, Molyneux SD, McKee TD, Waterhouse P, Penninger JM and Khokha R: RANKL blockade prevents and treats aggressive osteosarcomas. Sci Transl Med 7: 317ra197, 2015. (c) (i) () $९$ This work is licensed under a Creative Commons International (CC BY-NC-ND 4.0) License. 